\title{
Appraising Poverty Alleviation Programs of Successive Governments in Nigeria
}

\author{
Umar Tela \\ Department of Banking and Finance,The Federal Polytechnic Nasarawa,Nasarawa State. Nigeria.
}

\begin{abstract}
The world over, poverty and inequality are twain plaques ravaging the lives and destroying the essence of living across races, gender, and status. The results as devastating as it is unfathomable, world leaders and policy makers are groping for answers as social structures are depleted; motility rates have gone highand income distribution is a smeared rhetoric. Countries that have perceived these horrendous trends are devising strategies to combat the spurring menace while others heavily overwhelmed are finding it difficult to grasp the realities of these economic thunderbolts. While Africa is home to over One billion people and growing, almost half of the population is poor and vulnerable (World population review, 2014). Nigeria with a population of over 170 million is not only fighting poverty but also in combat with a myriad of challenges, ranging from a dearth of true leaders, to corruption, dilapidated infrastructure, health and nutritional issues.
\end{abstract}

Key words:Poverty alleviation, Program, Government, Nigeria, Africa

\section{Introduction}

Poverty is a peculiar situation where basic human needs are least satisfied leading to deprivation of economical, social, political and environmental benefits to which people are legitimately entitled (Okoye\&Onyukwu 2007). In recent times the poverty incidence in Nigeria has assumed a different dimension characterized with severe insecurity trends and massive corruption engendered by bad leadership. Aware of the grave consequences of poverty, successive Nigerian governments have designed and implemented numerous policies to tackle this menace and bring a lasting solution to the people. However, every effort towards this direction has not yielded the expected results. While some believe that bad governance brought about by ineffective leadership, massive corruption, low productivity, unemployment, debt-burden and conflicts are associated to failure of poverty eradication programs, others attributed the high level of poverty to macroeconomic distortion, globalization, high population growth rate and poor human resources development. It is generally believed that acute poverty can be reduced or eradicated through effective policy measure driven by sound leadership void of corruption, which is the key trust of this paper. The paper raises some fundamental questions concerning the kind of leaders in positions of authority in the country, the depth of policies and strategies designed to tackle poverty and the impact of these policies and its sustenance to poverty alleviation. What are the various policies measures adopted by the past governments in Nigeria that were directed at poverty alleviation and how they have impacted on the provision of social services? What are the mechanizing and processes for bringing together various agencies to cooperate around poverty alleviation objectives? This paper attempts to address some of these issues on many fronts, engaging both physical and non-physical challenges. Poverty reduction policies must integrate the will of the federal government, international agencies and donor organizations and the organized private sector.

\section{Objective}

The overall objective of the study is to appraise poverty alleviation programs of successive governments in Nigeria. To identify various challenges that has hampered the implementation of poverty alleviation programs and policies and recommends the way forward.

\section{Methodology}

Drawing from the review of literature with respect to the research strategies used in similar studies, the research methods adopted for this study include data culled out from books, journal articles, and government publications. Additionally, information was gathered from past governmental records and selected interaction from members of the public.

\section{Nigeria Poverty Profile}

According to National Bureau of Statistics survey (2009 - 2010) in the year 1980, 27.2 percent of Nigerians live in utter poverty. The composition at the states level demonstrated a maximum of 49.5 percent recorded for Plateau and Nasarawa State. This clearly showed that every state had poverty record of less than 50 percent. By 1985, the national poverty level had risen to 46.3 percent with 68.9 percent in Bauchi State 
(including Gombe State). By 1996, the percentage rose again to 65.6 with Kebbi, Sokoto and Zamfara (former Sokoto State) having the highest record of 83.6 percent Bauchi and Gombe State follows with an incidence of 83.5 percent. As at the year 2000 , the poverty record was assumed to have risen to 70 percent at the nationwide. And today, the increment has gone up to 84 percent with Borno State leading and followed by Niger State. Through the efforts of the Government and other developmental organization, the incidence of poverty in Nigeria dropped to $69.0 \%$ in the year 2010 while the total population is at 112.47 . In the Southern part, poverty had increased between years 1980 - 1996 but dropped in 2004, apart from the South-south zone that dropped in1992. In fact, all states except Bayelsa had more than half of their population in poverty circle. Comparatively, while poverty showed the Southeast with $26.7 \%$. This confirmed the findings by the World Bank study in Nigeria which showed that there were differences between the North and South with more concentration of the poor in the Northern zone (as cited in National Bureau of statistics, 2005) During the period between 1980 2004, the incidence of Urban poverty also has been on the increase, an indication that poverty is not only seen in the rural areas but also co-existed in urban cities of the country. In 1980, poverty rose from 28.3 to $51.4 \%$ in 1985 but declined to $46.0 \%$ before it rose again to $69.3 \%$ in 1996 and fell to63.3\% in 2004 (Tomori, 2006).

Nigeria Poverty Profile 1980 - 2010

\begin{tabular}{|l|l|l|l|l|l|l|l|}
\hline Region & $1980 \%$ & $1985 \%$ & $1990 \%$ & $1995 \%$ & $2000 \%$ & $2004 \%$ & $2010 \%$ \\
\hline National & 27 & 46 & 42 & 67 & 60.9 & 54.5 & 69.0 \\
\hline Urban & 17 & 38 & 37 & 59 & 63 & 58 & 52.0 \\
\hline Rural & 28 & 51 & 46 & 71 & 73 & 70 & 66.1 \\
\hline North East & 38 & 55 & 54 & 67 & 70 & 69 & 69.0 \\
\hline North West & 38 & 52 & 37 & 68 & 70 & 69 & 68 \\
\hline Central & 32 & 51 & 46 & 66 & 67 & 68 & 59.5 \\
\hline South East & 12 & 30 & 41 & 68 & 68 & 69 & 58.7 \\
\hline South West & 13 & 39 & 43 & 67 & 67 & 68 & 49.8 \\
\hline South - South & 13 & 46 & 41 & 67 & 67 & 68 & 55.5 \\
\hline
\end{tabular}

III. Summary

Vision 2010 Committee Report reveals that:

- $50 \%$ of Nigerians live below the poverty line.

- $40 \%$ have access to safe drinking water;

- $85 \%$ of the urban population lives in single houses with more than 7 occupants on the average.

- $62 \%$ of Nigerians have access to primary health care.

Most Nigerians take less than one-third of the minimum required protein and vitamins (Report2010 Committee; Edoh, 2003:71).

Poverty in Nigeria, a country with over 140 million people is all encompassing. The scourge has also shown a rising tendency in the past couple of decades accounting for the nations low development indicators and its ranking alongside the poorest nations in the world (United Nations, 2001 and OXFAM, 2003). The majority of Nigeria's population lives in poverty with insufficient income to cover minimum standards of food, water, shelter, medical care and schooling. Given the Nation's rich endowment with natural resources, its poverty profile presents a somber picture of a rich nation in decline (OXFAM, 2003).

\section{The National Development Era}

Before the advent of the Structural Adjustment Program (SAP) in 1986, which was the first governments conscious policy targeted at poverty reduction/eradication, previous efforts were orchestrated around National Development Plans, an economic growth strategy designed the raise the GDP level of the country through increasing the growth capacity of every sector. These developmental plans focused on health care, education, Agriculture and other infrastructural related projects that will at the long run enhance the quality of life of the people.

Many of the developmental projects were either directly carried out by the federal government or in partnership with international development agencies like the World Bank (WB) and African Development Bank (ADB). Some of the projects undertaken within these periods include: The River Basin Development Authority (RBDA), Rural Electrification Scheme (RES), The Agricultural Credit Guarantee Scheme (ACGS) and The Rural Banking Scheme (RBS) among others.

There were significant success achieved from these developmental plans, however, most of them could not be continued and therefore was not sustained. As a result of poor maintenance, lack of monitoring and supervisory capabilities, shift in focus by successive governments, the developmental programs lost its original intent and subsequently faded away. The National Developmental Plans only concentrated on the growth of the country's GDP and so there was no direct target at poverty eradication and income distribution. The poor were expected to benefit the result of the economic growth, which lacked a deliberate poverty targeted interventions. 
Thereafter, poverty continued because it was not focused in the National Development Plans. However successive government continued to adjust their focus towards poverty alleviation strategy through the efforts of the international community. Nigeria before the wakeup call of the Structural Adjustment Program (SPA), carried out various other programs Like the Operation Feed the Nation (OFN) established to improve Agricultural performance and Free Compulsory Primary Education (FCPE) designed to raise the standard of education in the country in1977, Green Revolution a wholesale agricultural strategy established to boost agricultural produce in 1980 and the Low Cost Housing Scheme (LCHS) to make housing affordable for all Nigerians.

Poverty Eradication Programs Of Nigerian Government 1986-1997

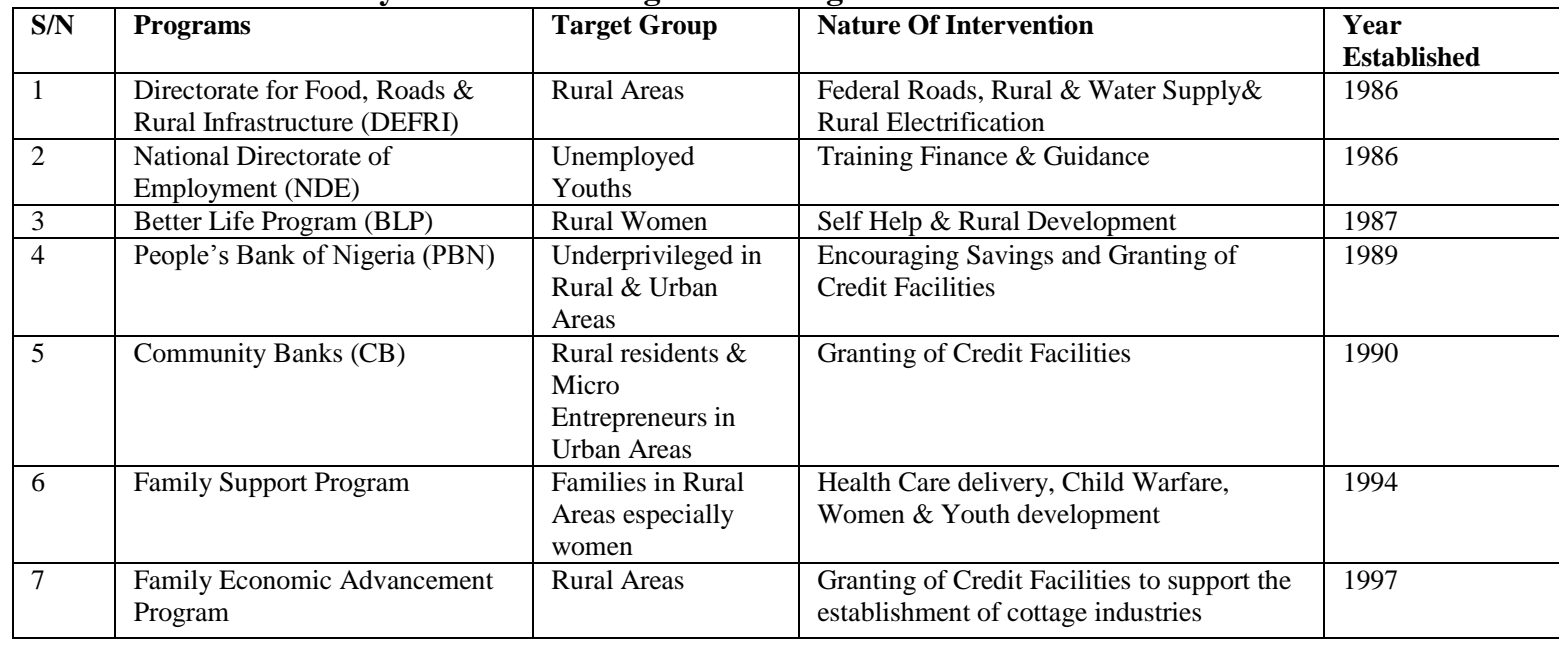

Poverty Eradication Programs of Nigerian Government Democratic Era2000- 2012

\begin{tabular}{|c|c|c|c|c|}
\hline $\mathbf{S} / \mathbf{N}$ & Programs & Target Group & Nature Of Intervention & $\begin{array}{l}\text { Year } \\
\text { Established }\end{array}$ \\
\hline 2 & $\begin{array}{l}\text { National Poverty Eradication } \\
\text { Program }\end{array}$ & Rural \& urban Areas & $\begin{array}{l}\text { Agriculture, Rural development, } \\
\text { Education \& Health }\end{array}$ & 2001 \\
\hline 3 & $\begin{array}{lr}\text { National } & \text { Economic } \\
\text { Empowerment } & \text { and } \\
\text { Development } & \text { Strategy } \\
\text { (NEEDS) } & \end{array}$ & Rural \& Urban Areas & $\begin{array}{l}\text { Addressing economic and social, } \\
\text { political and institutional issues }\end{array}$ & 2004 \\
\hline 4 & Vision 20-2020 & Rural \& Urban Areas & $\begin{array}{l}\text { Energy, Agriculture and Food Security } \\
\text { Wealth Creation, Land Reform } \\
\text { Security of Lives and Property } \\
\text { Education for Children } \\
\text { Transportation }\end{array}$ & 2007 \\
\hline
\end{tabular}

\section{An Overview of Sustainable Development Effort in Nigeria}

The centrality of poverty has made successive Nigerian governments to initiate sustainable development programs aimed at alleviating or minimizing the deadly scourge of the poverty phenomenon. According to Odion (2009) programs such as Operation Feed the Nation (OFN), which was launched in the 1970s, and Green Revolution initiated in 1980 existed in the past to address the problems of poverty either directly or indirectly. Other efforts made by successive governments include the establishment of the Directorate of Food, Roads and Rural Infrastructure (DEFFRI), National Directorate of employment (NDE), Better Life Program, (BLP), and the Peoples' Bank of Nigeria (PBN), Family Support program (FSP), Family Economic Advancement Program (FEAP), Poverty Alleviation Program (PAP), National Economic Empowerment and Development Strategy (NEEDs), Vision 20 - 2020 and the YouWINprogram. 


\section{Poverty Alleviation Programs \\ Directorate of Food, roads and Rural Infrastructure (DFRRI)}

Many of these programs had varied impact on poverty alleviation. For example, the establishment of the Directorate of Food, roads and Rural Infrastructure (DFRRI) was not only a radical departure from the previous programs, but also recognized the complementary associated with basic needs such as food, shelter, potable water, etc.DFRRI had tremendous impact on the rural areas. For instance, between the time of inception in 1986 and 1993, DFRRI had completed several roads. Over5, 000 rural communities benefited from its rural electrification program(CBNAnnual Reports1994).

This integrated approach to rural development, no doubt, provided for the necessary basic infrastructures that can stimulate the growth of agro - allied small - scale enterprises in rural areas. Furthermore, DFRRI impacted positively on food production. For instance, there was a steady and significant rise in agricultural output as shown by the index of agricultural production between 1986 and 1993 (CBN, Statistical Bulletin, December1998). However, DFRRI could not achieve many of its objectives due to many factors, which include lack of standards for project harmonization and effective mechanisms forco-ordination among the three tiers of government and between DFRRI and the levels ofgovernment (CBN Bauchi Zone; and Enugu Zone, 1998). Hence, with time DFRRIcould not sustain the tempo with which it started, and it ended up not living up to expectation and became defunct (National Planning Commission, 1994)The National Directorate of Employment (NDE) was the main organ for employment creation during this period. The objectives of NDE include: to design and implement programs to combat mass unemployment; and articulate policies aimed at developingwork programs with labor intensive potentials. Given that poverty manifests itself in the form of unemployment and underemployment, the schemes/Programs of NDEcould be said to have poverty alleviation focus. For instance the directorate has fourmain programs that not only creates jobs but also enhances the productivity andincome earning potentials of the youths and other beneficiaries. These programsinclude; the Vocational Skills Development Program (VSD), the Special Public worksProgram (SPW), the Small Scale Enterprises Program (SSE) and the AgriculturalEmployment Program.Available evidence shows that NDE has achieved remarkable progress in respect of itsvarious programs. Some of these include:

- The training of over 766,783 persons (including the disabled) in the National Open Apprenticeship Scheme between 1987 and 1996.

- Those who have benefited from the Resettlement scheme were over 106, 854 at the end of 1996.

- The School on Wheels Scheme had engaged youth 15,317 unemployed youths as at the end of 1994

- The Special Public Works Program has created jobs for over 154,910 persons between 1987 and 1996 (Central Bank Annual Reports, 1992 -1996). Besides, NDE as one of the institutions that survived the SAP era has continued to articulate development policies and programs with labor intensive potentials aimed at solving the unemployment problems in the country. However, the Directorate has not been adequately funded. Thus it has not been possible for NDE to cope with the needs of the ever-increasing number of job applicants in the country.

\section{The Better Life Program (BLP)}

The Better Life Program (BLP) was set up to enhance the quality of life of ruralwomen, among other objectives. Poverty in Nigeria is a rural phenomenon and the ruralwomen are worst hit by the dreadful malady of poverty; this is due to lack of basic skilland education necessary for gainful employment. The targeting of women in the fightagainst poverty will no doubt reduce significantly aggregate level of poverty in thecountry. The Better Life Program, therefore, tried to harness the potentials of ruralwomen and thereby impacted positively on their economic activities and incomes TheBLP improved the quality of life of many women through the distribution of variousinputs, granting of easy credits, and the establishment of variouseducational/enlightenment programs. Based on available evidence, Ogwumike (1988)concluded that the BLP made tremendous impact with regard to poverty alleviation. Inspecific terms, the achievements of BLP include the following: formationof 11,373women cooperatives by 1993; the establishment of 3,613 processing mills as well as thedistribution of farms inputs such as fertilizer to women who ordinarily would not havehad access to such inputs though they carry out the bulk agricultural activities. However,the success of the program was short - lived. The program was not only hijackedby position - seeking individuals but the resources set for the program were divertedand used for personal enrichment. 


\section{The People's Bank of Nigeria (PBN)}

The People's Bank of Nigeria (PBN) was set up to encourage savings and provide creditfacilities for the underprivileged in both urban and rural areas, Also, Community Banks (CB) were established to provide banking facilities for rural dwellers as well as tosupport micro - enterprises in urban areas (Oladeji \&Abiola, 1998). These two bankingschemes were established in recognition of the indispensable role of finance in povertyalleviation. Although the two banking schemes had some success, many of their goalsand objectives were never realized. The schemes have been bedeviled with manyadverse factors including corruption and gross mismanagement. For instance, late Tai-Solarin resigned as Chairman of peoples Bank because of alleged corruption/executiverascality that characterized the management of the bank.

\section{The Family Support Program (FSP)}

The Family Support Program (FSP)was set up to provide health caredelivery, child welfare, youth development, and improved nutritional status to families inrural areas. Also, the Family Economic Advancement Program (FEAP) was established to provide credit facilities to cooperative societies to support the establishment of cottage industries in both rural and urban areas. The program was also designed to create employment opportunities at ward levels, encourage the design and manufacture of appropriate plants, machinery and equipment's, and provide opportunities for the training of ward - based business operators. (Oladejiand\&Abiola, 1998). In a nutshell, both FSP and FEAP were designed and set up to improve the quality of life of rural dwellers. Although the FSP recorded several remarkable achievements such as the establishment of many nursery and primary schools, construction of many public toilets and the setting up of many vocational schools. Many of these projects were not properly executed and could not be sustained and many of the poor in several communities did not actually benefit from these projects while they lasted.

Nevertheless, it is important to note that most of the poverty alleviation strategies adopted in Nigeria were well focused on rural areas and on the agricultural sector. This is because poverty in Nigeria is largely a rural phenomenon with agriculture accounting for the highest incidence over the years. Besides, poverty reduction depends to a large extent on the agricultural sector, because the sector not only provides food for consumption as well as raw materials for manufacturing activities, it is the main employer of labor especially in the rural areas. Other several programs such as National Agricultural Land Development Authority (NALDA), the Agricultural Development Programs(ADP), and the Strategic Grains Reserves Programs (SGRP)have one way or the other impacted positively on the agricultural sector and by implication reduced poverty. Similarly, in the health, education and housing sectors are among the several povertyreducing programs, which were implemented. For example, the Primary Health Care Scheme and the Guinea Worm Eradication Program to mention just a few.Although the guinea worm eradication program recorded a tremendous success, the effectiveness of the primary health care program was grossly reduced due to inadequate funding, lack of equipment; essential drugs and trained manpower (see Egware, 1997).

In the housing sector, the National Housing Policy has brought about the national housing fund managed by the Federal Mortgage Bank of Nigeria. The Federal Housing Authority and various state governments have been involved in the direct construction of housing units. However, despite the efforts put in place in the housing sector, it is common knowledge that many Nigerians do not have decent accommodation. Many people live in congested rooms. Indeed, many Nigerians lack adequate accommodation and some are homeless as they sleep under bridges at night in many parts of the country (like Lagos) due to lack of adequate housing facilities or high cost of accommodation. The National housing scheme needs to be re-focused so as to make it accessible to majority of Nigerians. We can go on and on appraising various poverty alleviation programs in Nigeria. As stated earlier, on the whole, poverty alleviation programs/efforts in Nigeria failed to produce the desired results. The major reasons for the failure of poverty reduction related programs in Nigeria include program inconsistency, poor implementation, corruption of government officials and public servants, poor targeting mechanisms and failure to focus directly on the poor (see Kankwenda et al, 2000,Ogwumike, 1998; \&Egware, 1997).

In 2004, the Federal Government of Nigeria set up the NEEDs Strategy with a view to fighting the poverty scourge, which it described as the most difficult challenge facing Nigeria and its people and the greatest obstacle to the pursuit of socio-economic growth. Over the years attempts were made at alleviating poverty as reflected in the expression of commitment by successive governments, increase in the number of programs and increasing commitment of resources in the process, however, very minimal success has been recorded or achieved. This, according to Muo (2007) is largely due to lack of coordination and commitment, lack of continuity, improper appreciation of the roots and magnitude of the problem, poor funding of the programs, policy inconsistency, deficient infrastructural facilities and corruption. On the other hand, the Central Bank of Nigeria (2003) in its own view based on empirical investigation attributed the failure of poverty alleviation programs to deterioration in fiscal discipline, corruption, political instability and inconsistent policies. To crown it all, NEEDs (2004) pointed out several factors that had hindered the effort of government at reducing the level 
of poverty. These included poor coordination; the absence of a comprehensive policy framework, excessive political interference; ineffective targeting of the poor leading to leakage of benefits to unintended beneficiaries; the unwieldy scope of program which caused resources to be thinly spread across too many projects design, implementation, monitoring and evaluation. The evidence suggests that the reforms and policies have not recorded the spectacular results expected. Thus, poverty alleviation remains a mirage in Nigeria.

The Nigerian administration in 2007 proposed to provide a veritable development process by setting the target of catapulting Nigeria to become one of the top 20 economies in the world by the year 2020 tagged the long term perspective plan Vision 20-2020. The administration in its pursuit inaugurated the National Council and the National Steering Committee on Vision 20-2020, which promised to put an end to poverty using the United Nations Millennium Development Goals as a guide andpromised to confront poverty and develop Nigeria. The following was articulated as a seven point agenda

1. Agriculture and Food Security

2. Wealth Creation and Poverty Alleviation

3. Land Reform

4. Security of Lives and Property

5. Human Capital Development including compulsory Education for

6. Children

7. Transport Revolution including improved Mass Transit

At the end of the administration, the goals were never achieved, majorly because of poor leadership commitment towards pursuing the outlined objectives. Therefore there is an urgent need to move beyond plans and policies to taking practical steps toward achieving developmental gains. In this regard, collaboration between governments, international agencies and the organized private sector and civil society is crucial in creating the necessary synergy to ensure that the country achieve the Millennium Development Goals (MDGs) which will define Nigerian's economic priorities and strategies in a way that works for the majority of the citizens.

\section{The YouWINprogram}

In 2011 the current administration in partnership with the World Bank, Department for International Development and the organized private sector has projected Youth Enterprise with innovation in Nigeria. The YouWIN program allows young individuals with business initiatives to access loans of between 1 to 10 Million Naira to develop and deploy ideas that will employ people thereby creating jobs for them. This program was advertised nationally and some persons have won based on the criteria and have been given the soft loans to develop the business idea to ultimately become self-reliant and create jobs for others. The first phase of the YouWIN program has achieved so much success in the area of entrepreneurial development, capacity building and small and medium business development The second phase which is ongoing is targeting female entrepreneurs in the area of training, mentorship and networking capacities. While this program is ongoing, will it be a departure from the previous? The fact remains that a lot need to be done to achieve landmark result in poverty eradication in Nigeria.

\section{Recommendation and Conclusion}

Nigeria needs to define an economic philosophy underpinning a rational planning framework. Given that the vast majority of our people live in the rural areas, we cannot escape the question of agriculture and rural development. But that alone will not guarantee national transformation. Agriculture must be linked to a comprehensive industrial strategy so as to create jobs for the teeming millions of our unemployed youth. Nigeria's future lies in an agriculture led industrialization strategy, in which enhanced productivity in rural agriculture leads to industries that create new products that are higher up in the value chain and that aim at capturing international niche markets. We have opportunities to leapfrog our development by tapping into the potentials of sustainable energy systems and using ICT technologies to enhance productivity and welfare

For the Nigerian economy to achieve considerable progress relative to the inherent realizable potentials given the abundant human and material resource endowment, the issue of sound leadership must be addressed. The country is still grappling with numerous challenges, which has continued to militate against the achievement of economic transformation and the fight against poverty and income inequality. From the standpoint of leadership, the country is seriously weighed down with numerous shortcomings in the spheres of politics, corporate leadership even at the community level. Nigeria could be rightly classified as undergoing leadership decadence across all spectrum of human endeavor. The bane of leadership in our environment could conveniently be grouped into the following broad categories. 
- Prevalence of executive/legislative/judicial lawlessness and corruption within the body polity as the personal interests of many leaders override collective goals. The frenzied quest for wealth over and above all other considerations has rendered leadership most ineffective.

- Lack of leadership education and skills to discharge expected roles and perform leadership duties effectively.

- Inadequate motivation of subordinates and followers leading to disconnect in leadership and followership relationship.

- Abuse of power and manipulation of ethnic relationship, by those in positions of authority by way of nepotism, tribalism, favoritisms and religious bigotry.

Finally, a tripartite synergetic working relationship between the government, the international agencies and the private sector as the engine of growth is very crucial to the achievement of a poverty free Nigeria.

\section{References}

[1]. Central Bank of Nigeria, Enugu Zone (1998). A Profile of Regional/Zonal Poverty in Nigeria: The Case of Enugu Zone. Measuring and Monitoring Poverty in Nigeria, Proceedings of the Seventh Annual Conference of the Zonal Research Units.

[2]. Egware, L (1997). "Poverty and Poverty Alleviation: Nigeria's Experience". In Poverty

[3]. Alleviation in Nigeria, Selected Papers for the 1997 Annual Conference of Nigerian Economic Society.

[4]. Federal Office of Statistics (1999). Poverty Profile for Nigeria: 1980 - 1996

[5]. Ogwumike, F. O. (1995). "The Effects of Macro- level Government Policies onRural Development and Poverty Alleviation in Nigeria”. 1(1), 85-101.Ibadan Journal of the Social Sciences,

[6]. World population review.com/continents/ Africa - population/

[7]. Ogwumike, F. O. \&Aromolaran, A. B. (2000) Poverty Dynamics in Nigeria.

[8]. World Bank (1996). Nigeria: Poverty in the Midst of Plenty, the Challenge of Growth with Inclusion, A World Bank Poverty Assessment, World Bank, Washington, D. C.World Bank (2000),

[9]. World Development Report 2000/2000: Attacking Poverty, WorldBank, Washington, D. C. 